\title{
Rear Admiral (Astronaut) Alan Shepard: Ménière's disease and the race to the moon
}

\author{
Richard Menger, MD, MPA, ${ }^{1}$ Patrick Kelly, MD, ${ }^{2}$ Shanik Fernando, MD, ${ }^{3}$ Michael E. Wolf, MD, MS, ${ }^{4,5}$ \\ and Anthony Martino, MD ${ }^{6}$
}

\begin{abstract}
1Department of Neurosurgery, Louisiana State University Health Sciences Center, Shreveport, Louisiana; Departments of ${ }^{2}$ Neurosurgery and ${ }^{3}$ Otolaryngology, Vanderbilt University Medical Center, Nashville, Tennessee; ${ }^{4}$ Department of Occupational and Environmental Medicine, Department of Emergency Medicine, University of Pennsylvania, Philadelphia, Pennsylvania; ${ }^{5} \mathrm{SS}$ Navy, Airborne Command, Control, and Logistics Wing, Point Mugu, California; and ${ }^{6}$ Department of Neurosurgery, University of South Alabama, Mobile, Alabama
\end{abstract}

On May 5, 1961, Alan B. Shepard Jr. piloted the Freedom 7 craft into a suborbital flight to become the first American man in space. His promising astronautical career was soon scuttled by spells of dizziness and tinnitus later diagnosed as Ménière's disease, until William F. House-considered the father of neurotology and a pioneer in surgery for vestibular schwannomas-intervened. In 1968 House implanted an endolymphatic-subarachnoid shunt, which at the time was a virtually experimental procedure. Shepard's debilitating Ménière's disease was cured, but not quite in time for him to pilot the doomed Apollo 13 mission; he was reassigned to Apollo 14 and as a result would step foot on the moon on February 5,1971 . This historical vignette depicts the tale of how the career trajectories of Shepard and House-two notable figures in their respective fields-fatefully intersected.

https://thejns.org/doi/abs/10.3171/2018.9.JNS182522

KEYWORDS aerospace medicine; astronaut; space; history; William House; Ménière's disease; military history

$\mathrm{R}$ EELING from the social, financial, and political fallout of the Second World War, the climate of international relations from 1945 until 1989 was dominated by the Cold War raging between the US and the Union of Soviet Socialist Republics (USSR). In the midst of the nuclear arms race between the two nations, development of a nuclear weapon that would be deployable as an intercontinental ballistic missile served to spur a period of advances in rocket science. A fortunate byproduct of this arms race was that the theory and materials for rocket propulsion would prove ripe for co-optation for manned space flight. Although the US government showed little support for a space program initially, the launch of Sputnik on October 4, 1957, spurred the US into action. Thus began the so-called Space Race., ${ }^{7,7}$

Manned space flight was the next major benchmark of the early space programs after the USSR had sent a satellite into orbit. Although the Russians achieved this goal on April 12, 1961, with the launch of Yuri Gagarin into space aboard a Vostok-3A craft, the US was in close pursuit. By 1959 the newly formed National Aeronautics and Space Administration (NASA) had whittled down an extensive list of aspiring astronauts to the famed "Mercury Seven" (Fig. 1). ${ }^{34,37}$ NASA selected US Navy test pilot Alan B. Shepard Jr. (Fig. 2) from these 7 candidates to pilot the Freedom 7 craft (Fig. 3) on the US's first manned mission-Mercury-Redstone 3-and on May 5, 1961, Shepard became the first American man in space when he completed a 15-minute, 28 -second suborbital flight. ${ }^{27}$

Shepard instantaneously became a national hero. His future astronautical aspirations were soon dashed, however, with the onset of a debilitating case of Ménière's disease, which would keep him grounded and relegated to a desk job in NASA administration leadership. It would take years of failed conservative and medical management before Shepard found himself in the office of preeminent neurotologist William F. House discussing an experimental new procedure-an endolymphatic-subarachnoid

ABBREVIATIONS NASA = National Aeronautics and Space Administration; USSR = Union of Soviet Socialist Republics . ACCOMPANYING EDITORIAL See pp 301-303. DOI: 10.3171/2018.11.JNS182794.

SUBMITTED August 31, 2018. ACCEPTED September 28, 2018.

INCLUDE WHEN CITING Published online February 15, 2019; DOI: 10.3171/2018.9.JNS182522. 


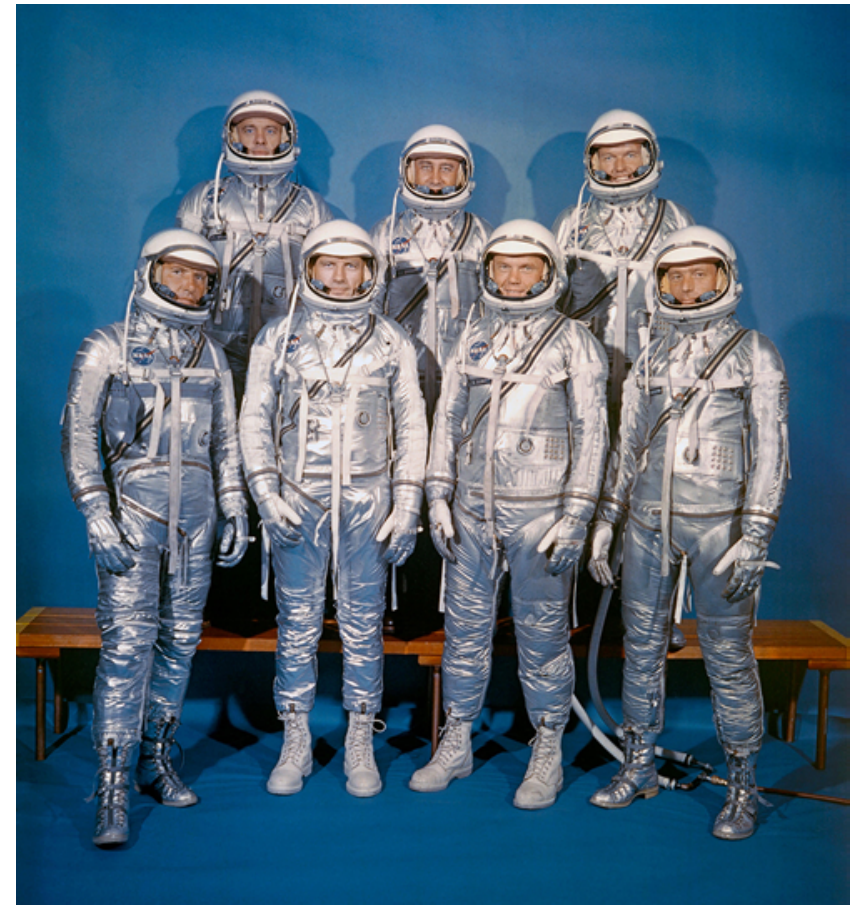

FIG. 1. The Mercury Seven astronauts. Front row, left to right: Walter M. Schirra Jr., Donald K. Slayton, John H. Glenn Jr., and M. Scott Carpenter. Back row, left to right: Alan B. Shepard Jr., Virgil I. Grissom, and L. Gordon Cooper Jr. Dated July 1960. Photograph courtesy of NASA. Figure is available in color online only.

shunt-for the treatment of his inner-ear disease. The procedure was remarkably successful, allowing Shepard to regain flight readiness just prior to selection of the Apollo 13 crew. Ultimately, a fortuitous administrative shuffling of crew assignments bumped Shepard from the roster of the ill-fated Apollo 13 mission to Apollo 14, which would allow him to land on the moon. . $^{6,24,25,33}$

This is the story of how an experimental skull base procedure would change the course not only of Alan Shepard's life, but that of the history of American space exploration.

\section{Astronaut Alan Shepard}

Alan Bartlett Shepard Jr. was the son of retired Army Colonel "Bart" Shepard and Renza Emerson. Alan and his younger sister Polly had a comfortable upbringing in East Derry, New Hampshire, by virtue of their grandfather's prominent local business interests in banking and electricity. Shepard grew up in the age of Charles Lindbergh and as a child he aspired to become a pilot. US entry into World War II was imminent just as Shepard was finishing high school; although he followed in his father's footsteps in joining the military, he broke with tradition and applied to the US Naval Academy given his better prospects for eventual flight training in that branch of the armed services. ${ }^{33,37} \mathrm{He}$ left home in 1941 for the academy, graduated in 3 years, completed his requisite year of service aboard the USS Cogswell (with a brief leave to marry his long-time sweetheart Louise Brewer), and returned to Corpus Christi to pursue his true passion: flight. ${ }^{23,37}$

Shepard received his wings in 1947 and deployed with

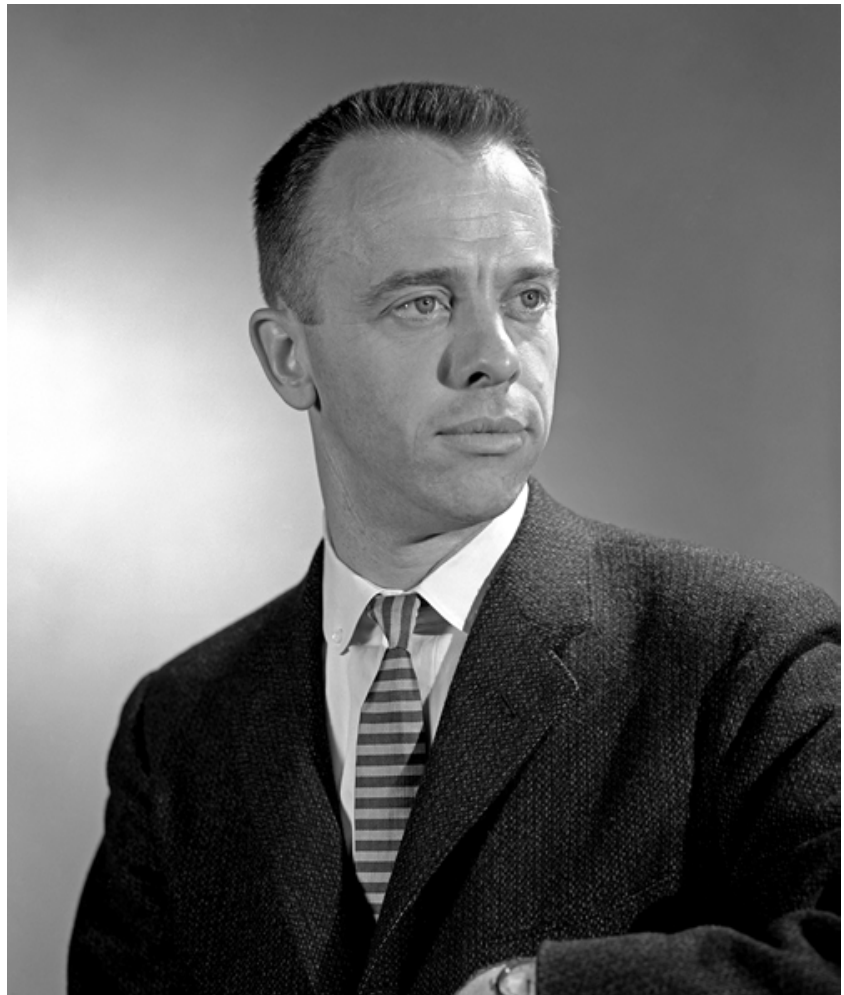

FIG. 2. Photograph of Alan B. Shepard Jr., dated May 14, 1959. Photograph courtesy of NASA.

Fighter Squadron 42 aboard a series of aircraft carriers in the Mediterranean. ${ }^{23}$ That same year President Truman signed the National Security Act establishing the Air Force as a separate branch of the armed forces. By 1950 the US Navy was recruiting its best pilots to join the ranks of its test pilot program at Patuxent River to edge out this new competing branch of the military. Not surprisingly, Shepard was selected as one of the 25 members of the fifth class of the test pilot school, and was the youngest member, at that. ${ }^{37}$

Shepard led a successful test pilot career for several years, although he had occasional demerits for risky flight behavior such as "flat hatting"-flying extremely low over crowds or structures. One particularly dangerous infraction nearly earned Shepard a court martial when he "flat hatted" a public beach in Maryland and then looped his jet underneath the newly constructed Chesapeake Bay bridge. Despite these blemishes on his military record, he was eventually transferred to the Naval War College in Newport, Rhode Island. On the evening of October 4, 1957, he watched from his backyard in Newport as Sputnik careened across the night sky. Finally spurred into action, the US government announced the creation of NASA 2 months later and Shepard was on the short list for the first US astronaut by January 1959. After months of intense training and preparation, Shepard piloted the Freedom 7 craft into suborbital space flight (Fig. 4).

The mission was a technical success, but unbeknownst to NASA, Shepard had already experienced a harbinger of his inner ear affliction to come. In early 1959 after selection as one of the Mercury Seven, Shepard was out golfing 


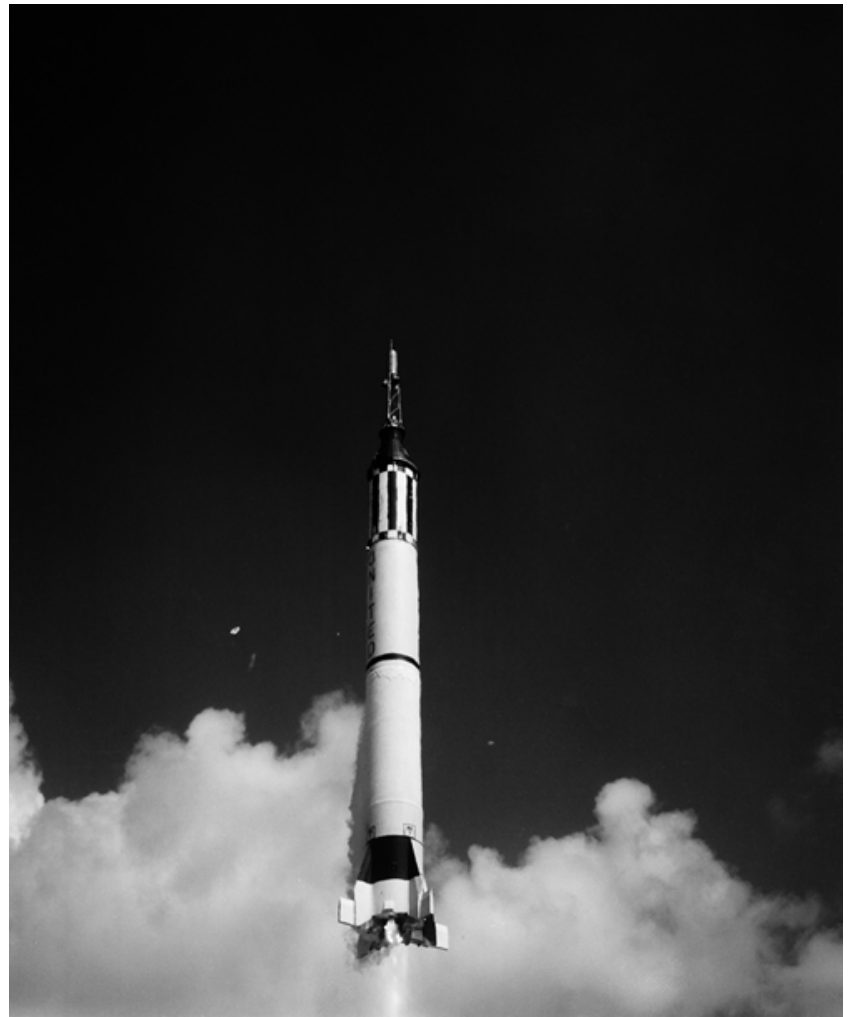

FIG. 3. Liftoff of the Mercury-Redstone 3 rocket and the Freedom 7 capsule from Cape Canaveral. Dated May 5, 1961. Photograph courtesy of NASA.

with his father and a colleague from the Navy when he suddenly began to feel dizzy. He tried to push through, but after two holes his shots had become so erratic and dizziness so severe that he decided he couldn't finish. He swore his companions to secrecy and enjoyed a brief remission of the episodes until they would return in $1963 .{ }^{37}$

Immediately after the Mercury-Redstone 3 mission Shepard set his sights on one of the manned Gemini missions. Fortuitously, his friend and co-member of the Mercury Seven, Deke Slayton, had just assumed leadership of the astronaut office and was able to grant him his wishShepard would join Tom Stafford in the two-seated Gemini craft. By that time the spells had unfortunately returned. As the spells progressed, though, he eventually gave in and saw a private physician, who started him on diuretics and niacin. The treatment was ineffective, and only 6 weeks into his Gemini training the attacks of Ménière's went from bothersome to crippling. ${ }^{37}$

The dizziness was soon accompanied by tinnitus and bouts of vomiting that kept Shepard from being able to drive. He continued with his training for several weeks, but his condition was revealed publicly when he stumbled and staggered away from the podium during a speech in Houston. NASA physicians got involved, and grounded him. Further diuretic therapy was attempted unsuccessfully, and the grounding became permanent. Shepard was dedicated to the cause of space travel and decided to remain with NASA, now relegated to a desk job as head of

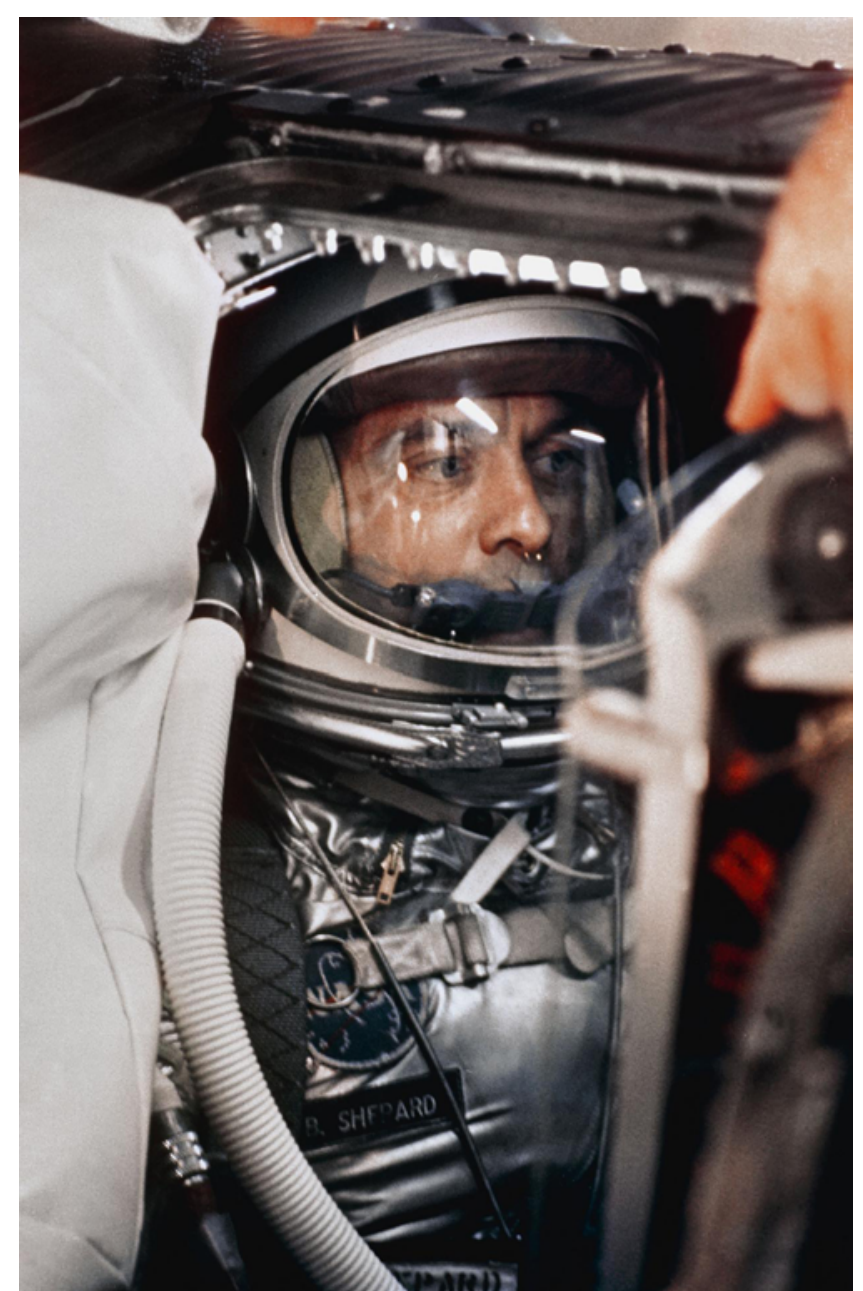

FIG. 4. Alan B. Shepard Jr. with space suit and helmet, seated in the Freedom 7 craft during a flight simulation. Dated April 29, 1961. Photograph courtesy of NASA. Figure is available in color online only.

the astronaut office. ${ }^{33,37}$ A small chance remained, though, that he might be made flight ready once more if his Ménière's could only be treated.

\section{Ménière's Disease}

Dating back to antiquity, vertigo was seen as a malady of the 4 humors-later renamed apoplectiform cerebral congestion. Physicians treated the condition with bleeding, leeching, cupping, and purging well into the 19th century. ${ }^{4}$ Prosper Ménière first implicated the inner ear in the phenomenon of vertigo in his 1861 paper presented to the Imperial Academy of Medicine in Paris. ${ }^{21}$ In this manuscript (and in his 5 follow-up papers from that year), Ménière described a syndrome of vertigo, hearing loss, and tinnitus with which he was intimately familiar as the physician-inchief of the Parisian Imperial Institute for Deaf-Mutes.,36 The syndrome was named in Ménière's honor in 1872, but wasn't until 1938 that Hallpike and Cairns identified pathological dilation of the endolymphatic system-or endolymphatic hydrops-as the underpinning of the condition. $^{13,36}$ 
There remains a paucity of data regarding epidemiology of the disease, but the rates in the published literature among a variety of populations vary between 17 and 46 people per $100,000 .^{32}$ It is more commonly diagnosed in female patients and those of European descent, and typically presents in the 4th and 5th decades of life. ${ }^{32}$ Symptoms of the disease typically encompass spontaneous and episodic vertigo with episodes lasting minutes to days, low-frequency hearing loss, tinnitus, and aural fullness. Diagnosis of Ménière's is contingent on the presence of vestibular symptoms characterized by episodes of vertigo with variable inclusion of the cochlear symptoms (hearing loss, tinnitus, aural fullness).

The pathophysiology of the disease is not well understood. Genetic, autoimmune, infectious, traumatic, and vascular etiologies have all been proposed as causing Ménière's disease. Overall, the underlying pathology is thought to be idiopathic disruption of homeostasis of ions in solution within the endolymph, making treating the symptoms a challenge for clinicians. ${ }^{1,8,28,39}$

\section{Surgical Treatment of Ménière's Disease}

Treatment for Ménière's disease is primarily medical; in acute exacerbations sedatives and antiemetics provide symptom control, and diuretics or vasodilators comprise chronic therapy regimens. ${ }^{11}$ Surgical treatments remain only a second-line therapy for Ménière's since Georges Portmann first described the surgical technique of opening the endolymphatic sac in $1927.11,16,29,30$

To this day, endolymphatic sac surgery remains the first surgical option for failed medical management of Ménière's. The primary advantage of this type of procedure is that it preserves cochlear nerve function and carries relatively low morbidity. There are many varieties of endolymphatic sac surgery, but these generally fall into either endolymphatic sac decompression or shunting; decompression consists of a mastoidectomy with careful removal of the bone overlying the endolymphatic sac, whereas shunting adds an additional step in which the lining of the sac is lanced and allows drainage of endolymph. ${ }^{19}$ Shunting may include placement of a T-shaped shunt tube into the sac (draining into the mastoid), or insertion of a small silastic sheet into the sac to encourage continued drainage of endolymph into the mastoid space..$^{35}$

In the setting of failed endolymphatic sac surgery, further surgical options include vestibular nerve section, which entails a small posterior fossa craniotomy, opening of the dura mater, and isolated sectioning of the vestibular nerve. Finally, labyrinthectomy serves as a last-resort ablative surgical option considered for patients with poor hearing in the affected ear in whom conservative management has failed. Although the procedure is highly effective, both vestibular and cochlear nerve function are completely lost.

\section{Ménière's in Military Pilots}

Ménière's disease, then, poses a serious threat to both auditory and vestibular senses-two essential sensory modalities for a pilot like Alan Shepard. Although Ménière's is not associated with an increased risk of accidents in the general population, pilots are exquisitely dependent on the vestibular sense for spatial orientation and on hearing for radio communication. ${ }^{2}$ Unfortunately no studies have specifically addressed the prevalence or special considerations of Ménière's disease in astronauts or pilots, although several case reports highlight the serious implications of the disease for flight suitability. ${ }^{12,17,18}$

The unpredictable nature of Ménière's disease leads most authorities to recommend against a return to flying for a modern-day pilot who has received this diagnosis. This is due to a large number of those affected experiencing recurrence of their symptoms, with $30 \%-50 \%$ of patients progressing from unilateral to bilateral disease within 2 years of symptom onset. ${ }^{39}$ For those individuals who do seek a return to flying, a waiver of qualification standards is not generally considered until the patient has been symptom free for 1 year, and even then only a minority of requests are granted, typically for those who fly aircraft that are flown by 2 pilots and have dual flight controls.

\section{Dr. William House}

William Fouts House (Fig. 5) is considered by many to be the father of neurotology. ${ }^{5}$ Originally intending to become an oral maxillofacial surgeon, House graduated from the University of California at Berkeley doctoral program in dentistry in 1945. After a brief stint as a Navy dentist he returned to California to complete medical school at the University of California at Los Angeles, decided instead to pursue a career in otolaryngology, and filled the single residency position at Los Angeles County Hospital thereafter. ${ }^{5}$ In that period, widespread use of penicillin had obviated the need for many traditional otological surgical procedures, and many physicians considered otolaryngology a dying field. But otology was truly in its infancy, and William House had a lifetime of innovation ahead of him to contribute to it. ${ }^{5,38}$

In the course of his career, William House introduced the use of the intraoperative microscope and diamond burr drill to the field of otology, fostered one of the first otology-neurosurgery operative teams, created a single-handed suction-irrigator, and developed the translabyrinthine approach for resection of cerebellopontine angle tumors. $5,15,20$ A mere 10 days before Alan Shepard would be officially selected for the Mercury-Redstone 3 mission, House implanted the world's first cochlear implant, which he had developed, perhaps the crowning achievement of his career. ${ }^{22,37}$ Despite intermittent controversy about human experimentation and criticism from colleagues, House remained dedicated to the cause of implantable auditory devices, performing the first auditory brainstem implant in 1979 and continuing to develop single-channel cochlear implants throughout his career..$^{10}$ But the paths of William House and Alan Shepard would cross long before that.

\section{"Sounds Like a Hell of an Idea"}

In 1962-his 6th year in practice-House published his technique for endolymphatic-subarachnoid shunt insertion for the treatment of Ménière's disease ${ }^{16}$ Enthusiasm for endolymphatic sac surgery in the 1960s had waned due to a dearth of studies demonstrating efficacy, but House believed that the popular technique at the time-largely 
unchanged from Portmann's original 1927 procedureprobably did not lead to durable decompression of endolymph. That historical approach consisted of a posterior fossa craniotomy and lancing of the endolymphatic sac where it merges with the dura along the posterior aspect of the petrous temporal bone..$^{16,29,30}$

House tried a number of innovative methods of inducing lasting decompression of the endolymphatic sac by using a variety of implants until he found the endolymphaticsubarachnoid shunt to be most effective. The procedure consists of a posterior fossa craniotomy, identification of the endolymphatic sac, and then insertion of an 8- $\mathrm{mm}$ flexible silicone shunt tube from the subarachnoid space into the sac. His series of 7 patients showed remarkable improvement in hearing, speech discrimination, and resolution of vertigo attacks. ${ }^{16}$

In the summer of 1968, fellow astronaut Tom Stafford approached Alan Shepard about an otolaryngologist in Los Angeles who was gaining notoriety for his innovative surgical procedures, including one to treat Ménière's. Shepard was nearing desperation so he took Stafford's recommendation and flew out to meet Dr. House. They discussed the procedure, acknowledged its potential ineffectiveness, and decided to move forward anyway (even in spite of Shepard's Christian Scientist faith). "Sounds like a hell of an idea to me. Let's go for it," Shepard remarked. ${ }^{31}$ "Victor Poulos"-a pseudonym chosen by House's clinic nurse-was admitted to St. Vincent's Hospital in Los Angeles later that summer for his surgery and was discharged home a mere 2 days later. Alan Shepard was back at the astronaut office within the week. ${ }^{14,37}$

\section{Tale of Two Apollo Flights}

Within 6 months Alan Shepard was symptom-free. Dr. House soon formally declared that the Ménière's was cured, but by that time Shepard's priority was already set on flight clearance. ${ }^{33} \mathrm{He}$ traveled to Pensacola with NASA flight surgeon Charles A. Berry and underwent an exhaustive battery of tests; despite the brutal sessions in the centrifuge and high-altitude flights, Shepard's hearing, balance, and grit did not waver. ${ }^{26,33}$ All that he needed now was Dr. Berry's approval. As Berry would later explain, "I feel my job is to keep people qualified to fly," and that's exactly what these tests confirmed-Shepard was ready.

Shepard wasted no time returning to NASA headquarters to make a plea for a spot on the next mission. The unwritten rule at the time was that the backup crew for each mission would be assigned as the primary crew for the third mission thereafter. For example, Neil Armstrong and Buzz Aldrin served on the backup crew for Apollo 8, which positioned them to be the primary crew for Apollo 11 and would ultimately catapult them into the annals of history.

Once his flight status was public knowledge, Shepard was designated commander of Apollo 13, taking the spot of Apollo 10 backup crewmember Astronaut Gordon Cooper, who was under scrutiny from NASA due to a variety of training-related issues. Deke Slayton, then in charge of astronaut mission selection, sent off the roster for Apollo 13 to include Alan Shepard, Stuart Roosa, and Edgar

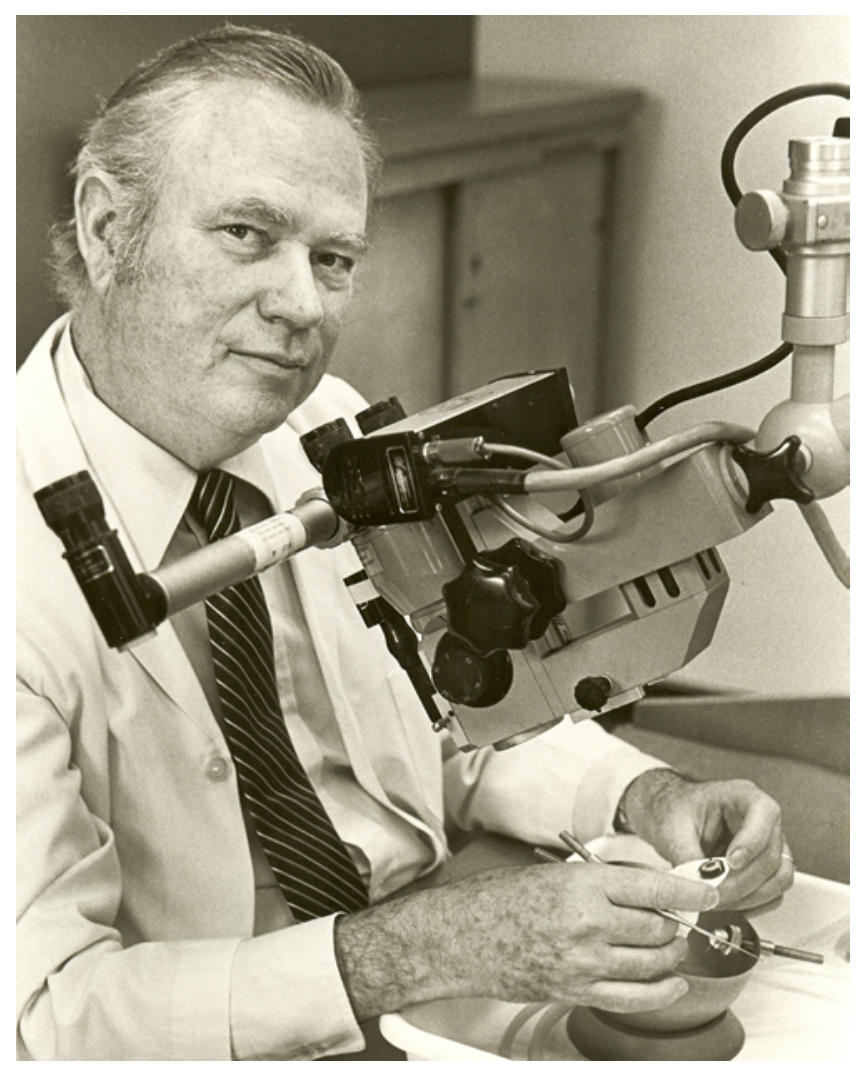

FIG. 5. Photograph of Dr. William F. House. Photograph courtesy of the House Ear Institute. Printed with permission from John W. House. Figure is available in color online only.

Mitchell. For the first time in the space program, however, the administration did not accept the recommendation. Shepard had been grounded for several years, and concerns regarding his readiness to fly had made their way not only to George Mueller at NASA headquarters but also directly to Richard Nixon; Shepard's plans were quickly deflated. $26,31,33,37$

Shepard and his hand-selected crew were conceded the Apollo 14 mission in consolation, and were scheduled for another year of training and preparation until then. Meanwhile, Apollo 13 launched on April 11, 1970, with James Lovell, Fred Haise, and Jack Swigert. It embarked on its famed, nearly catastrophic mission, without Alan Shepard. Fifty-five hours into the mission an oxygen tank on the service module of the spacecraft exploded, igniting a series of critical failures and almost depleting the oxygen and power supply of the ship. Mission control-with the help of Shepard-managed to right the course of the ship and conserve enough power and oxygen for the crew to return home safely. ${ }^{24,31}$

Apollo 14 was cleared to proceed after a 4-month delay for equipment upgrades to avoid the same disaster. In the irony of ironies, it was Shepard's medical status and unsuccessful attempt to command Apollo 13 that ultimately would afford him the chance to land on the moon. ${ }^{25,37}$ In fact, Alan Shepard was the only one of the original Mercury Seven astronauts, selected in 1959, who walked on the moon. He was also the oldest, at age 47. 


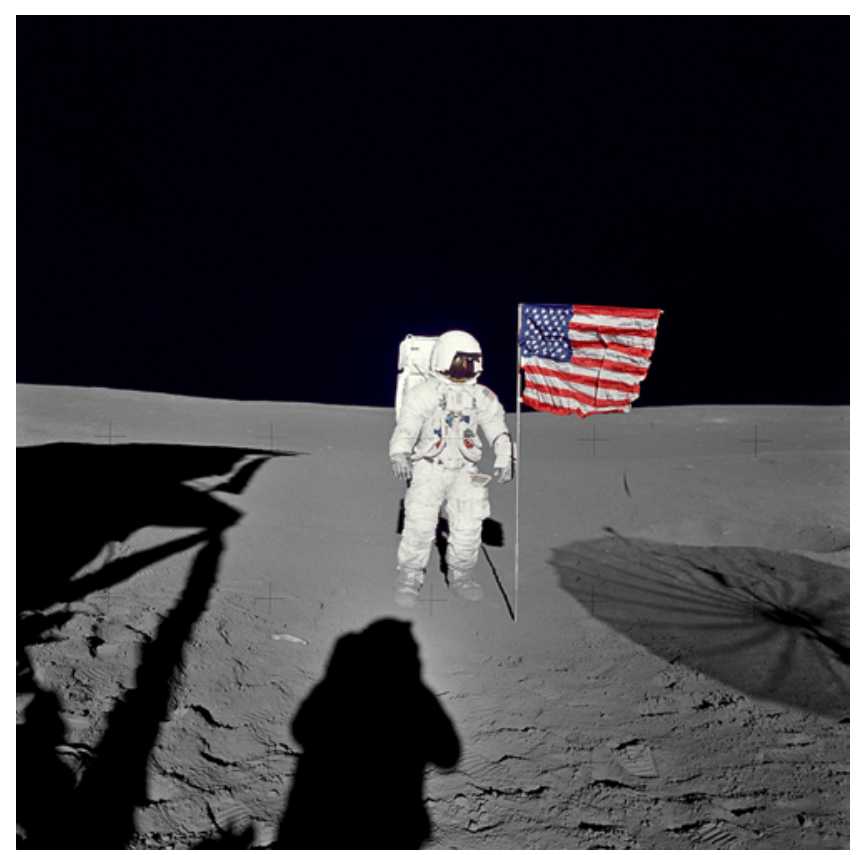

FIG. 6. Alan B. Shepard Jr. during the first extravehicular activity of the Apollo 14 mission. Photograph courtesy of NASA. Figure is available in color online only.

\section{Conclusions}

Apollo 14 lifted off from Cape Canaveral on January 31, 1971, carrying Alan Shepard-at last-toward the moon. ${ }^{25}$ Just a mile away sat William House and his wife June at the VIP viewing area, special guests at Shepard's invitation. ${ }^{14}$ Several days later, House arrived at Mission Control in Houston where he had the opportunity to speak to Shepard via radio as well; "I'm talking to you through the ear that you operated on!" Shepard exclaimed. ${ }^{37} \mathrm{Had}$ it not been for William House's practically experimental procedure, the course of Shepard's life and perhaps the Apollo missions would have been inexorably changed.

Apollo 14 was successful by all accounts; on February 5 the lunar module touched down on the moon, Shepard spent a total of 9 hours and 17 minutes of the next day and a half traversing the lunar surface, and took the opportunity to use a makeshift 6 iron to chip a golf ball off into the distance before departing back to re-dock with the command module (Fig. 6). The command module safely returned to Earth, splashing down on February 9, 1971. 14,25,31

Shepard continued working for NASA and ultimately achieved the rank of Navy Rear Admiral, while House continued innovating in the field of neurotology and the skull base. ${ }^{5,23}$ The two remained friends for many years and Shepard, curiously, was even named a director of the Los Angeles Ear Institute. ${ }^{23}$ Sadly, Alan Shepard died in 1998 of leukemia and William House succumbed to metastatic melanoma in 2012, although both left lasting legacies. Although politics, war, and the military-industrial complex have all profoundly affected the development of both neurosurgery and otolaryngology, the saga of Alan Shepard, William House, and Ménière's disease provides a quintessential example of medicine directing the course of history. ${ }^{9,40}$

\section{References}

1. American Society of Aerospace Medicine Specialists: Clinical Practice Guideline for Meniere's Disease. Alexandria, VA: Aerospace Medical Association, 2001 (http://www. asams.org/guidelines/Completed/NEW\%20Meniere $\% 27 \mathrm{~s} \% 20$ Disease.htm) [Accessed November 28, 2018]

2. Atzema CL, Grewal K, Lu H, Kapral MK, Kulkarni G, Austin PC: Outcomes among patients discharged from the emergency department with a diagnosis of peripheral vertigo. Ann Neurol 79:32-41, 2016

3. Baloh RW: Prosper Ménière and his disease. Arch Neurol 58:1151-1156, 2001

4. Baloh RW: Vertigo: Five Physician Scientists and the Quest for a Cure. Oxford: Oxford University Press, 2016

5. Berliner KI: In Memoriam: William F. House, DDS, MD, the "Father of Neurotology" (1923-2012). JAMA Otolaryngol Head Neck Surg 139:202-203, 2013

6. Berry CA, Hoffler GW, Jernigan CA, Kerwin JP, Mohler SR: History of space medicine: the formative years at NASA. Aviat Space Environ Med 80:345-352, 2009

7. Chapman S: From red star rising to rocket's red glare: space travel, the early years. Phys Educ 42:335, 2007

8. Davis JR, Johnson R, Stepanek J: Fundamentals of Aerospace Medicine. Philadelphia: Lippincott Williams \& Wilkins, 2008

9. Dowdy J, Pait TG: The influence of war on the development of neurosurgery. J Neurosurg 120:237-243, 2014

10. Eisenberg LS: The contributions of William F. House to the field of implantable auditory devices. Hear Res 322:52-56, 2015

11. Flores García ML, Llata Segura C, Cisneros Lesser JC, Pane Pianese C: Endolymphatic sac surgery for Ménière's disease-current opinion and literature review. Int Arch Otorhinolaryngol 21:179-183, 2017

12. Guyot JP: Should a pilot suffering from Ménière's disease be grounded or lifted off to the moon? ORL J Otorhinolaryngol Relat Spec 58:304-305, 1996

13. Hallpike CS, Cairns H: Observations on the pathology of Meniere's syndrome. Proc R Soc Med 31:1317-1336, 1938

14. Hicks J: The doctor behind Shepard's Apollo 14 flight. Los Angeles Times. July 25, 1998 (http://articles.latimes. com/1998/jul/25/local/me-6898) [Accessed November 28, 2018]

15. House WF: The acoustic neuroma saga. J Laryngol Otol 109:367-368, 1995

16. House WF: Subarachnoid shunt for drainage of endolymphatic hydrops. A preliminary report. Laryngoscope 72:713-729, 1962

17. Johnson GP: Cases from the aerospace medicine residents' teaching file. Case \#39. Ménière's disease. Aviat Space Environ Med 61:1160-1162, 1990

18. Kortschot HW, Oosterveld WJ: A pilot suffering from Ménière's disease. A case report. ORL J Otorhinolaryngol Relat Spec 57:316-318, 1995

19. Lasak JM, Welling DB: Endolymphatic mastoid shunt surgery. Oper Tech Otolaryngol Head Neck Surg 12:133-136, 2001

20. Martin D: Dr. William F. House, inventor of pioneering earimplant device, dies at 89. The New York Times. December 15, 2012 (https://www.nytimes.com/2012/12/16/health/drwilliam-f-house-inventor-of-cochlear-implant-dies.html) [Accessed November 28, 2018]

21. Meniere P: Sur une forme de surdite grave dependant d'une lesion de l'oreille interne. Bull Acad Med XXVI:241, 1861

22. Mudry A, Mills M: The early history of the cochlear implant: a retrospective. JAMA Otolaryngol Head Neck Surg 139:446-453, 2013

23. National Aeronautics and Space Administration: Alan B. Shepard, Jr. (Rear Admiral, USN, Ret.). Washington, DC: 
NASA, 1998 (https://www.nasa.gov/sites/default/files/atoms/ files/shepard_alan.pdf) [Accessed November 28, 2018]

24. National Aeronautics and Space Administration: The Apollo Missions: Apollo 13. Washington, DC: NASA, 2009 (https:// www.nasa.gov/mission_pages/apollo/missions/apollo13.html) [Accessed November 28, 2018]

25. National Aeronautics and Space Administration: The Apollo Missions: Apollo 14. Washington, DC: NASA, 2009 (https:// www.nasa.gov/mission_pages/apollo/missions/apollo14.html) [Accessed November 28, 2018]

26. National Aeronautics and Space Administration: NASA Johnson Space Center Oral History Project: Edited Oral History Transcript: Charles A. Berry. Washington, DC: NASA, 1999 (https://www.jsc.nasa.gov/history/oral_histories/ BerryCA/BerryCA_4-29-99.htm) [Accessed November 28, 2018]

27. National Aeronautics and Space Administration. NASA Missions. Washington, DC: NASA, 2018 (https://www.nasa.gov/ missions) [Accessed November 28, 2018]

28. Navy Medicine Operational Training Center: Meniere's disease/vertigo, in U.S. Navy Aeromedical Reference and Waiver Guide. Pensacola, FL: NMOTC, 2018, Sect 6.6

29. Portmann G: The saccus endolymphaticus and an operation for draining the same for the relief of vertigo. J Laryngol Otol 42:809-817, 1927

30. Portmann G: Vertigo: surgical treatment by opening the saccus endolymphaticus. Arch Otolaryngol 6:309-319, 1927

31. Rincon P: Apollo 14 moon shot: Alan Shepard 'told he was too old'. BBC News. February 4, 2011 (https://www.bbc.com/ news/science-environment-12344613) [Accessed November 28, 2018]

32. Sajjadi H, Paparella MM: Meniere's disease. Lancet 372:406-414, 2008

33. Shepard AB, Slayton D: Moon Shot: The Inside Story of America's Race to the Moon. Atlanta: Turner Publishing, 1994

34. Siddiqi AA: Challenge to Apollo: The Soviet Union and the Space Race, 1945-1974. Washington, DC: NASA, 2000

35. Sood AJ, Lambert PR, Nguyen SA, Meyer TA: Endolymphatic sac surgery for Ménière's disease: a systematic review and meta-analysis. Otol Neurotol 35:1033-1045, 2014

36. Stothers HH: XXV Prosper Menière: The Centenary of an Eponym. Ann Otol Rhinol Laryngol 70:319-336, 1961
37. Thompson N: Light This Candle: The Life and Times of Alan Shepard. New York: Three Rivers Press, 2005

38. Tremble GE: Half a century of otolaryngology. Can Med Assoc J 76:34-37, 1957

39. Van Syoc D: Vertiginous disorders, peripheral (Meniere's disease, benign paroxysmal positional vertigo, vestibular neuronitis [labyrinthitis]), in Air Force Waiver Guide. WrightPatterson AFB, OH: US Air Force School of Aerospace Medicine, 2014, pp 1033-1045 (https://www.wpafb.af.mil/ Portals/60/documents/711/usafsam/USAFSAM-WavierGuide-Jan\%202018.pdf) [Accessed November 28, 2018]

40. Weir N: Otorhinolaryngology. Postgrad Med J 76:65-69, 2000

\section{Disclaimer}

The views expressed are those of the authors and do not reflect the official policy or position of the National Aeronautics and Space Administration, United States Navy, United States Navy Reserve, Department of Defense, or the United States Government.

\section{Disclosures}

The authors report no conflict of interest concerning the materials or methods used in this study or the findings specified in this paper.

\section{Author Contributions}

Conception and design: Menger, Martino. Acquisition of data: Kelly, Menger, Fernando, Wolf. Analysis and interpretation of data: Kelly, Fernando, Wolf. Drafting the article: Kelly, Menger, Fernando, Wolf. Critically revising the article: Kelly, Menger, Fernando, Wolf. Reviewed submitted version of manuscript: Kelly, Fernando, Martino. Approved the final version of the manuscript on behalf of all authors: Kelly. Administrative/technical/material support: Kelly. Study supervision: Menger, Martino.

\section{Correspondence}

Patrick D. Kelly: Vanderbilt University Medical Center, Nashville, TN. patrick.d.kelly@vumc.org. 